\title{
Yimella lutea gen. nov., sp. nov., a novel actinobacterium of the family Dermacoccaceae
}

\author{
Correspondence \\ Wen-Jun Li \\ wjli@ynu.edu.cn \\ or \\ liact@hotmail.com
}

\author{
Shu-Kun Tang, ${ }^{1} \dagger$ Jin-Yuan Wu, ${ }^{1} \dagger$ Yun Wang, ${ }^{2}$ Peter Schumann ${ }^{3}$ \\ and Wen-Jun $\mathrm{Li}^{1,4}$
${ }^{1}$ The Key Laboratory for Microbial Resources of the Ministry of Education, and Laboratory for Conservation and Utilization of Bio-Resources, Yunnan Institute of Microbiology, Yunnan University, Kunming 650091, PR China 830091, PR China D-38124 Braunschweig, Germany Chinese Academy of Sciences, Guangzhou 510301, PR China \\ ${ }^{2}$ Xinjiang Institute of Microbiology, Xinjiang Academy of Agricultural Science, Urumqi, Xinjiang \\ ${ }^{3} \mathrm{DSMZ}$ - Deutsche Sammlung von Mikroorganismen und Zellkulturen GmbH, Inhoffenstrasse 7B, \\ ${ }^{4}$ Guangdong Key Laboratory of Marine Materia Medica, South China Sea Institute of Oceanology,
}

The family Dermacoccaceae was first proposed by Stackebrandt \& Schumann (2000) and its pattern of 16S rRNA signature nucleotides was emended by Zhi et al. (2009). At the time of writing, the family Dermacoccaceae comprises the genera Dermacoccus (Stackebrandt et al., 1995), Demetria (Groth et al., 1997) and Kytococcus (Stackebrandt et al., 1995). Most strains have been isolated from human skin. They are Gram-positive, aerobic, nonencapsulated, non-endospore-forming, catalase-positive, non-halophilic, coccoid actinobacteria and the peptidoglycan type is variation $\mathrm{A} 4 \alpha$.

Strain YIM $45900^{\mathrm{T}}$, a Gram-stain-positive, coccoid, nonmotile, halotolerant actinobacterium, was found in the laboratory of Yunnan Institute of Microbiology, China, as a contaminant on a modified ISP medium 5 (Shirling \&

†These authors contributed equally to this work.

The GenBank/EMBL/DDBJ accession number for the 16S rRNA gene sequence of strain YIM $45900^{\top}$ is FJ528304.
Gottlieb, 1966) agar plate (containing $1^{-1}$ distilled water: $1 \mathrm{~g}$ L-asparagine, $10 \mathrm{~g}$ glycerol, $5 \mathrm{~g}$ yeast extract, $1 \mathrm{~g}$ $\mathrm{K}_{2} \mathrm{HPO}_{4}, 5 \mathrm{~g} \mathrm{KNO}_{3}, 50 \mathrm{~g} \mathrm{NaCl}, 15 \mathrm{~g}$ agar; final $\mathrm{pH}$ 7.5). $\mathrm{NaCl}$ was sterilized separately before being added to the medium. Strain YIM $45900^{\mathrm{T}}$ was maintained on ISP 2 (Shirling \& Gottlieb, 1966) agar slants at $4{ }^{\circ} \mathrm{C}$ and in $20 \%$ $(\mathrm{w} / \mathrm{v})$ glycerol suspensions at $-20{ }^{\circ} \mathrm{C}$. Biomass for chemical and molecular studies was obtained by cultivation in shaken flasks (about 150 r.p.m.) using ISP 2 broth (pH 7.5) at $28{ }^{\circ} \mathrm{C}$ for about 1 week.

Cell morphology was determined on cultures grown for 6 , $12,24,48$ and $72 \mathrm{~h}$ on ISP 2 agar medium at $28{ }^{\circ} \mathrm{C}$. Gram staining was carried out by the standard Gram reaction and was confirmed by using KOH lysis (Cerny, 1978). Spore formation was determined by staining with malachite green. Cell motility was confirmed by the development of turbidity throughout a tube containing semisolid medium (Leifson, 1960). Morphological characteristics of the strain were observed by light microscopy (model BH 2; Olympus) 
and by transmission electron microscopy (model H-800; Hitachi). The growth temperature was tested at $4-55{ }^{\circ} \mathrm{C}$ at intervals of $2{ }^{\circ} \mathrm{C}$ on ISP medium 2 . For $\mathrm{NaCl}$ tolerance experiments, ISP medium 2 was used as the basal medium and salt concentrations ranging from 0 to $20 \%(\mathrm{w} / \mathrm{v})$ at intervals of $1 \%$ were tested. The $\mathrm{pH}$ growth range was investigated between $\mathrm{pH} 4.0$ and 10.0 at intervals of $1 \mathrm{pH}$ unit, using the following buffer systems: $\mathrm{pH} 4-50.1 \mathrm{M}$ citric acid/0.1 M sodium citrate; $\mathrm{pH} 6-80.1 \mathrm{M} \mathrm{KH}_{2} \mathrm{PO}_{4} /$ $0.1 \mathrm{M} \mathrm{NaOH} ;$ pH 9-10 0.1 M NaHCO$/ 0.1 \mathrm{M} \mathrm{Na}_{2} \mathrm{CO}_{3}$. Catalase activity was determined by production of bubbles after the addition of a drop of $3 \% \mathrm{H}_{2} \mathrm{O}_{2}$. Oxidase activity was observed by oxidation of tetramethyl-p-phenylenediamine. Methyl red and Voges-Proskauer tests and tests for melanin production and milk peptonization and hydrolysis of aesculin, casein, cellulose, chitin, dextrin, DNA, gelatin, starch, urea and Tweens 20, 40, 60 and 80 were performed as described by Cowan \& Steel (1965). Oxidation of different substrates was tested using GP2 MicroPlates (Biolog). Enzyme activities and acid production from carbohydrates were determined by using the API 20E, API ZYM and API 50CH systems (bioMérieux) according to the manufacturer's instructions. Anaerobic growth was determined using the GasPak Anaerobic System (BBL) according to the manufacturer's instructions. The morphological, cultural and physiological properties of strain YIM $45900^{\mathrm{T}}$ are given in the genus and species descriptions. The organism can be distinguished from members of the family Dermacoccaceae using a range of phenotypic properties (Table 1).

The peptidoglycan structure of the cell wall of strain YIM $45900^{\mathrm{T}}$ was determined by using established procedures (Schleifer \& Kandler, 1972; Schleifer, 1985; MacKenzie, 1987). Sugar analysis of the purified cell wall followed procedures described by Staneck \& Roberts (1974). Polar lipids were extracted, examined by two-dimensional TLC and identified using described procedures (Minnikin et al., 1984). Menaquinones were isolated according to Minnikin et al. (1984) and separated by HPLC (Kroppenstedt, 1982). For fatty acid analyses, cells of strain YIM $45900^{\mathrm{T}}$ were cultured on tryptic soy agar (Difco) at $28{ }^{\circ} \mathrm{C}$ for 4 days. Cellular fatty acids analysis was performed as described by Sasser (1990) using the Microbial Identification System (MIDI).

The peptidoglycan of strain YIM $45900^{\mathrm{T}}$ contained Ala, Gly, Ser, Asp, Glu and Lys in a molar ratio of $1.6: 1.0: 0.7: 0.8: 1.0: 1.2$. The peptide Lys-Ser, which is stable under hydrolytic conditions in $4 \mathrm{M} \mathrm{HCl}$ at $100{ }^{\circ} \mathrm{C}$ for $16 \mathrm{~h}$, was detected. Aspartic acid was revealed by dinitrophenylation to represent the $\mathrm{N}$ terminus of the interpeptide bridge. From these data, it was concluded that strain YIM $45900^{\mathrm{T}}$ contained the peptidoglycan type $\mathrm{A} 4 \alpha$ with a L-Lys-L-Ser-D-Asp interpeptide bridge and a glycine residue bound to the $\alpha$-carboxyl group of D-glutamic acid at position 2 of the peptide subunit. The cell-wall sugars were galactose and fucose (with a minor amount of mannose and traces of glucose). The polar lipids consisted of diphosphatidylglycerol, phosphatidylinositol, glucosamine-containing phospholipid and one unknown phospholipid. The predominant menaquinone was $\mathrm{MK}-8\left(\mathrm{H}_{4}\right)$ $(97.2 \%)$; a minor amount of MK-8 $\left(\mathrm{H}_{6}\right)(2.8 \%)$ was detected. Strain YIM $45900^{\mathrm{T}}$ had a cellular fatty acid profile that contained major amounts $(>10 \%)$ of branched fatty acids, iso- $\mathrm{C}_{15: 0}(35.2 \%)$, anteiso- $\mathrm{C}_{15: 0}(12.1 \%)$ and anteiso- $\mathrm{C}_{17: 0}(11.1 \%)$, and minor amounts of branched, straight-chain, unsaturated and methyl fatty acids, iso$\mathrm{C}_{13: 0}(4.2 \%)$, anteiso- $\mathrm{C}_{13: 0}(2.4 \%)$, iso- $\mathrm{C}_{14: 0}(0.5 \%)$, $\mathrm{C}_{14: 0}(3.0 \%), \mathrm{C}_{15: 0}(1.0 \%)$, iso- $\mathrm{C}_{16: 1} \mathrm{H}(0.5 \%)$, iso- $\mathrm{C}_{16: 0}$ (4.8\%), $\mathrm{C}_{16: 0}$ cis-9 (3.3\%), $\mathrm{C}_{16: 0}$ (5.7\%), $\mathrm{C}_{16: 0}$ 9-methyl $(2.0 \%)$, anteiso- $\mathrm{C}_{17: 1} \mathrm{C}(0.8 \%)$, iso- $\mathrm{C}_{17: 0}(5.5 \%), \mathrm{C}_{17: 1}$ cis-9 $(1.0 \%), \mathrm{C}_{17: 0}(0.5 \%), \mathrm{C}_{18: 1}$ cis-9 $(2.0 \%)$ and $\mathrm{C}_{18: 1}$ $2-\mathrm{OH}(1.6 \%)$.

Extraction of genomic DNA and PCR amplification of the 16S rRNA gene sequence were performed as described by Li et al. (2007). Multiple alignments with sequences from the most closely related members of the suborder Micrococcineae and calculations of levels of sequence similarity were carried out using the EzTaxon server 2.0 (Chun et al., 2007). Phylogenetic analyses were performed using three tree-making algorithms, the neighbour-joining (Saitou \& Nei, 1987), maximum-likelihood (Felsenstein, 1981) and maximum-parsimony (Fitch, 1971) methods. A phylogenetic tree was constructed using the neighbourjoining method from $K_{\text {nuc }}$ values (Kimura, 1980) using MEGA version 4.0 (Tamura et al., 2007). The topology of the phylogenetic tree was evaluated by the bootstrap resampling method of Felsenstein (1985) with 1000 resamplings. The genomic DNA of strain YIM $45900^{\mathrm{T}}$ for the determination of $\mathrm{G}+\mathrm{C}$ content was prepared according to the method of Marmur (1961). The G $+C$ content of the DNA was determined by reversed-phase HPLC of nucleosides according to Mesbah et al. (1989).

An almost-complete 16S rRNA gene sequence (1446 bp) was determined for strain YIM $45900^{\mathrm{T}}$. Comparative $16 \mathrm{~S}$ rRNA gene sequence analysis showed that strain YIM $45900^{\mathrm{T}}$ fell within the radius of the suborder Micrococcineae (Fig. 1). Its closest phylogenetic neighbours were members of the genera of the family Dermacoccaceae. Strain YIM $45900^{\mathrm{T}}$ showed $16 \mathrm{~S}$ rRNA gene sequence similarities of $95.9,95.9,95.7,95.6,94.0,93.5$ and $93.1 \%$ to the type strains of Dermacoccus profundi, Dermacoccus barathri, Dermacoccus abyssi, Dermacoccus nishinomiyaensis, Demetria terragena, Kytococcus sedentarius and Kytococcus schroeteri, respectively. This relationship was supported by all three tree-making methods (data not shown). The $\mathrm{G}+\mathrm{C}$ content of the DNA was $65.8 \mathrm{~mol} \%$.

Strain YIM $45900^{\mathrm{T}}$ was similar to members of the genera of the family Dermacoccaceae (Dermacoccus, Kytococcus and Demetria), which have lysine as the diagnostic diamino acid, and different from members of the genera of the family Dermabacteraceae (Dermabacter and Brachybacterium) and Dermatophilaceae (Dermatophilus and Kineosphaera), which have meso- $\mathrm{A}_{2} \mathrm{pm}$ as the diagnostic 
Table 1. Differential phenotypic and chemotaxonomic characteristics of the genus Yimella gen. nov. and related genera of the family Dermacoccaceae

Strains: 1, Yimella lutea gen. nov., sp. nov. YIM $45900^{\mathrm{T}}$ (data from this study); 2, Demetria terragena HKI 0089 ${ }^{\mathrm{T}}$ (Groth et al., 1997); 3 , Dermacoccus nishinomiyaensis DSM $20448^{\mathrm{T}}$ (Stackebrandt et al., 1995); 4, Kytococcus sedentarius DSM $20547^{\mathrm{T}}$ (Stackebrandt et al., 1995). +, Positive; v, variable; - , negative; ND, no data available.

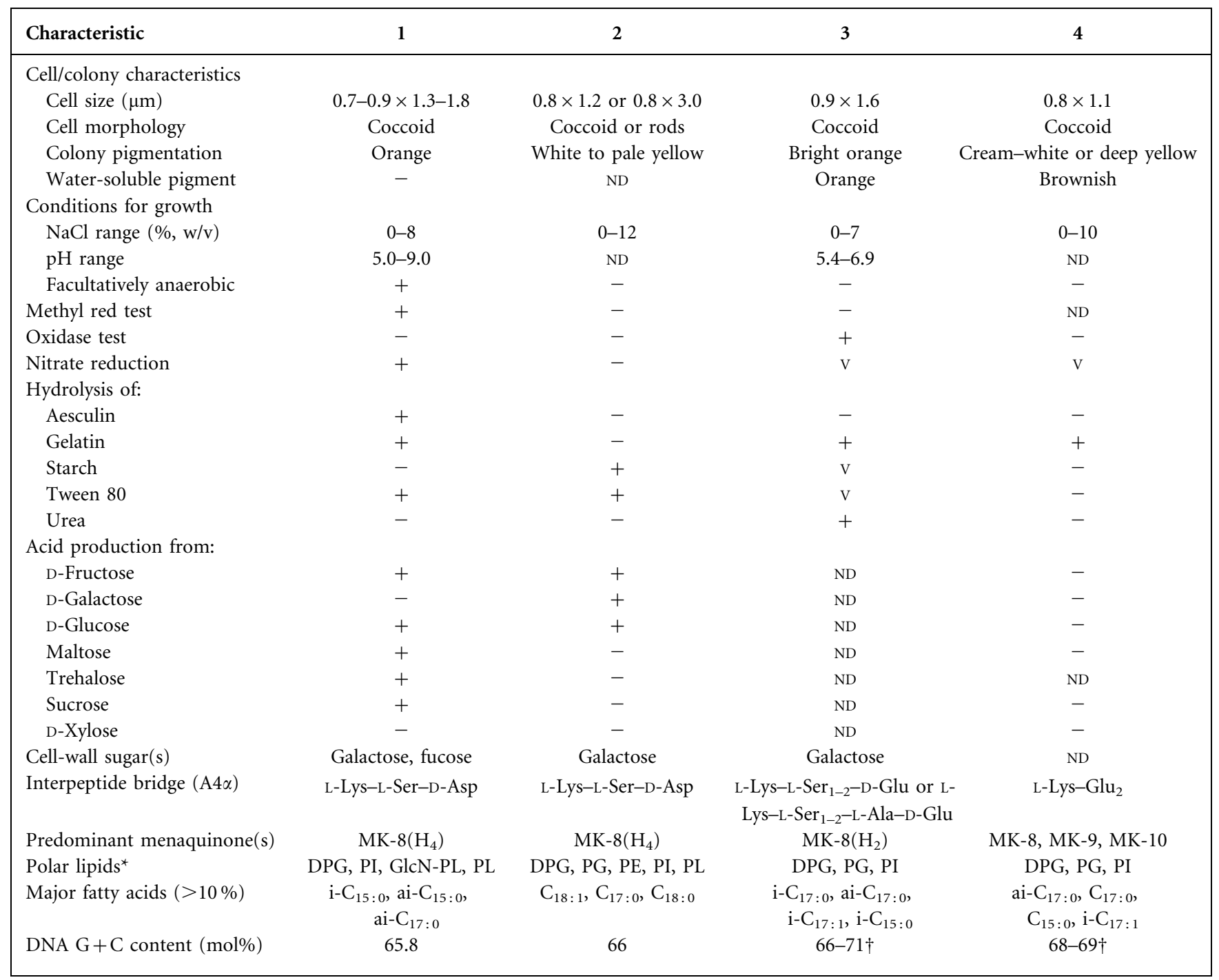

${ }^{\star}$ DPG, Diphosphatidylglycerol; GlcN-PL, glucosamine-containing phospholipid; PE, phosphatidylethanolamine; PG, phosphatidylglycerol; PI, phosphatidylinositol; PL, unknown phospholipid.

$\dagger$ Range of values for several strains, including the type strain.

diamino acid. In the phylogenetic tree based on the neighbour-joining algorithm, all of the type strains of the family Dermacoccaceae together with strain YIM $45900^{\mathrm{T}}$ clustered in a distinct clade that was strongly supported by a bootstrap value of $60 \%$. All of the above data confirmed that the isolate should be assigned to the family Dermacoccaceae. However, strain YIM $45900^{\mathrm{T}}$ formed a monophyletic branch within the radiation occupied by the three genera of the family Dermacoccaceae. Moreover, strain YIM $45900^{\mathrm{T}}$ could be differentiated from the genera Dermacoccus and Kytococcus in some chemotaxonomic properties (Table 1), i.e. strain YIM $45900^{\mathrm{T}}$ had L-Lys-LSer-D-Asp as the interpeptide bridge of the peptidoglycan and $\mathrm{MK}-8\left(\mathrm{H}_{4}\right)$ as the predominant menaquinone, whereas the members of genus Dermacoccus show L-Lys-L-Ser ${ }_{1-2}-\mathrm{D}-$ Glu or L-Lys-L-Ser ${ }_{1-2}-\mathrm{L}-\mathrm{Ala}-\mathrm{D}-\mathrm{Glu}$ as the interpeptide bridge and $\mathrm{MK}-8\left(\mathrm{H}_{2}\right)$ as the predominant menaquinone and the genus Kytococcus contains L-Lys-Glu $\mathrm{Gl}_{2}$ as the interpeptide bridge and MK-8, MK-9 and MK-10 as the predominant menaquinones. Although strain YIM $45900^{\mathrm{T}}$ was similar to the genus Demetria in containing L-Lys-LSer-D-Asp as the interpeptide bridge and MK- $8\left(\mathrm{H}_{4}\right)$ as the 


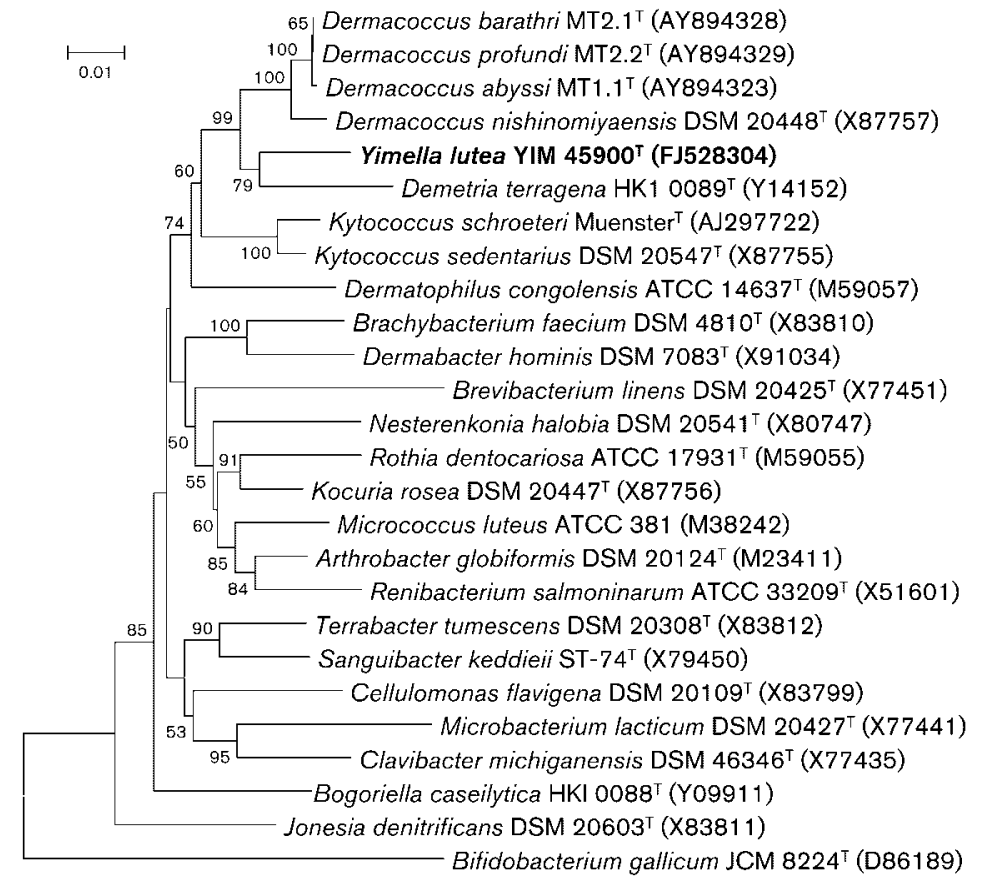

Fig. 1. Phylogenetic dendrogram obtained by distance-matrix analysis of 16S rRNA gene sequences, showing the position of strain YIM $45900^{\top}$ and its phylogenetic neighbours. Bootstrap values $(\geqslant 50 \%)$ based on 1000 resamplings are shown at branch nodes. The sequence of Bifidobacterium gallicum JCM $8224^{\top}$ was used as an outgroup. Bar, $1 \%$ sequence divergence. predominant menaquinone, it could be differentiated from the genus Demetria by the occurrence of a glycine residue bound to the $\alpha$-carboxyl group of D-glutamic acid of the peptide subunit and by the polar lipid pattern, as strain YIM $45900^{\mathrm{T}}$ contained a glucosamine-containing phospholipid but no phosphatidylethanolamine. In particular, strain YIM $45900^{\mathrm{T}}$ was quite different from the genus Demetria in its fatty acid profile, i.e. strain YIM $45900^{\mathrm{T}}$ contained major amounts of branched fatty acids (iso$C_{15: 0}$, anteiso- $C_{15: 0}$ and anteiso- $C_{17: 0}$ ) whereas the genus Demetria contained major amounts of straight and unsaturated fatty acids $\left(\mathrm{C}_{17: 0}, \mathrm{C}_{18: 0}\right.$ and $\left.\mathrm{C}_{18: 1}\right)$. Therefore, on the basis of chemotaxonomic and phylogenetic differentiation of the isolate from its closest neighbours in the family Dermacoccaceae, we propose that strain YIM $45900^{\mathrm{T}}$ represents a novel species in a new genus, Yimella lutea gen. nov., sp. nov.

\section{Description of the genus Yimella gen. nov.}

Yimella (Yi.mel'la. L. fem. dim. suff. -ella; N.L. fem. dim. n. Yimella arbitrary name formed from the acronym of Yunnan Institute of Microbiology, YIM, where the first taxonomic studies of this taxon were performed).

Cells are Gram-stain-positive, coccoid, non-encapsulated, halotolerant, aerobic and facultatively anaerobic in the presence of $\mathrm{KNO}_{3}$. They do not form endospores. The peptidoglycan is of the type A4 $\alpha$ with a L-Lys-L-Ser-D-Asp interpeptide bridge and a glycine residue bound to the $\alpha$ carboxyl group of D-glutamic acid at position 2 of the peptide subunit. The cell-wall sugars contain galactose and fucose. The predominant menaquinone is $\mathrm{MK}-8\left(\mathrm{H}_{4}\right)$. The polar lipids are diphosphatidylglycerol, phosphatidylinositol, a glucosamine-containing phospholipid and an unknown phospholipid. The major fatty acids are iso- $\mathrm{C}_{15: 0}$, anteiso$\mathrm{C}_{15: 0}$ and anteiso- $\mathrm{C}_{17: 0}$. The $\mathrm{G}+\mathrm{C}$ content of the DNA is about $65-66 \mathrm{~mol} \%$. The type species is Yimella lutea.

\section{Description of Yimella lutea sp. nov.}

Yimella lutea (lu.te'a. L. fem. adj. lutea orange-coloured).

Cells are approximately spherical $(0.7-0.9 \times 1.3-1.8 \mu \mathrm{m})$ on ISP 2 medium, non-motile and arranged in irregular clusters. The orange colonies on ISP 2 agar are circular, smooth, opaque and non-pigmented. Temperature, $\mathrm{pH}$ and $\mathrm{NaCl}$ tolerance ranges for growth are $22-42{ }^{\circ} \mathrm{C}, \mathrm{pH} 5.0-9.0$ and $0-8 \%$ and optimal growth occurs at $28{ }^{\circ} \mathrm{C}, \mathrm{pH} 6.0-7.0$ and $0-1 \%$. Catalase and methyl red tests are positive. Oxidase and Voges-Proskauer tests are negative. Gelatin, cellulose and Tweens 20, 40, 60 and 80 are hydrolysed, but casein, dextrin, starch, DNA, chitin and urea are not hydrolysed. Nitrate reduction and melanin production are positive. Milk peptonization and coagulation, $\mathrm{H}_{2} \mathrm{~S}$ and indole production, arginine dihydrolase, lysine decarboxylase, ornithine decarboxylase and tryptophan deaminase are negative. With the API ZYM system, positive for alkaline phosphatase, esterase (C4), esterase lipase (C8), leucine arylamidase, valine arylamidase, cystine arylamidase, trypsin, $\alpha$-chymotrypsin, naphthol-AS-BI-phosphohydrolase, $\beta$-glucuronidase and $\alpha$-glucosidase, but negative for lipase (C14), $\alpha$ - and $\beta$-galactosidases, $\beta$-glucosidase, $N$ acetyl- $\beta$-glucosaminidase, $\alpha$-mannosidase and $\alpha$-fucosidase. With Biolog GP2 MicroPlates, oxidizes Tweens 40 and 80, D-fructose, trehalose, $\alpha$-D-glucose, D-mannose, sucrose, maltose, D-xylose, acetic acid, D-ribose, propionic acid, pyruvic acid, glycerol, uridine, D-tagatose, turanose, Larginine, glycine, L-histidine and xanthine. Acid is pro- 
duced from aesculin, D-fructose, D-glucose, glycerol, Dmannose, maltose, sucrose, D-tagatose, trehalose, turanose and potassium 5-ketogluconate, but not from $\mathrm{N}$-acetylglucosamine, D-adonitol, amygdalin, DL-arabitol, arbutin, DLarabinose, cellobiose, dulcitol, erythritol, DL-fucose, Dgalactose, gentiobiose, glycogen, inositol, inulin, lactose, D-lyxose, D-mannitol, melezitose, melibiose, D-raffinose, Lrhamnose, D-ribose, salicin, D-sorbitol, L-sorbose, starch, DL-xylose, methyl $\beta$-D-xylopyranoside, methyl $\alpha$-D-mannopyranoside, methyl $\alpha$-D-glucopyranoside, xylitol, potassium gluconate or potassium 2-ketogluconate. The DNA G+C content of the type strain is $65.8 \mathrm{~mol} \%$.

The type strain is YIM $45900^{\mathrm{T}}\left(=\mathrm{DSM} 19828^{\mathrm{T}}=\mathrm{KCTC}\right.$ $19231^{\mathrm{T}}=$ CCTCC AB $207007^{\mathrm{T}}$ ), isolated from a contaminated agar plate.

\section{Acknowledgements}

The authors are grateful to Dr Jean Euzéby for the Latin construction of the generic name. This research was supported by the National Basic Research Program of China (2010CB833800), the Key Project of International Cooperation (2007DFB31620) and the National Natural Science Foundation of China $(30860002,30870005)$.

\section{References}

Cerny, G. (1978). Studies on aminopeptidase for the distinction of Gram-negative from Gram-positive bacteria. Eur J Appl Microbiol Biotechnol 5, 113-122.

Chun, J., Lee, J.-H., Jung, Y., Kim, M., Kim, S., Kim, B. K. \& Lim, Y. W. (2007). EzTaxon: a web-based tool for the identification of prokaryotes based on $16 \mathrm{~S}$ ribosomal RNA gene sequences. Int J Syst Evol Microbiol 57, 2259-2261.

Cowan, S. T. \& Steel, K. J. (1965). Manual for the Identification of Medical Bacteria. London: Cambridge University Press.

Felsenstein, J. (1981). Evolutionary trees from DNA sequences: a maximum likelihood approach. J Mol Evol 17, 368-376.

Felsenstein, J. (1985). Confidence limits on phylogenies: an approach using the bootstrap. Evolution 39, 783-789.

Fitch, W. M. (1971). Toward defining the course of evolution: minimum change for a specific tree topology. Syst Zool 20, 406-416.

Groth, I., Schumann, P., Rainey, F. A., Martin, K., Schuetze, B. \& Augsten, K. (1997). Demetria terragena gen. nov., sp. nov., a new genus of actinomycetes isolated from compost soil. Int J Syst Evol Microbiol 47, 1129-1133.

Kimura, M. (1980). A simple method for estimating evolutionary rates of base substitutions through comparative studies of nucleotide sequences. J Mol Evol 16, 111-120.

Kroppenstedt, R. M. (1982). Separation of bacterial menaquinones by HPLC using reverse phase (RP18) and a silver loaded ion exchanger as stationary phases. J Liq Chromatogr 5, 2359-2387.
Leifson, E. (1960). Atlas of Bacterial Flagellation. London: Academic Press.

Li, W. J., Xu, P., Schumann, P., Zhang, Y. Q., Pukall, R., Xu, L. H., Stackebrandt, E. \& Jiang, C. L. (2007). Georgenia ruanii sp. nov., a novel actinobacterium isolated from forest soil in Yunnan (China), and emended description of the genus Georgenia. Int J Syst Evol Microbiol 57, 1424-1428.

MacKenzie, S. L. (1987). Gas chromatographic analysis of amino acids as the $N$-heptafluorobutyryl isobutyl esters. J Assoc Off Anal Chem 70, 151-160.

Marmur, J. (1961). A procedure for the isolation of deoxyribonucleic acid from microorganisms. J Mol Biol 3, 208-218.

Mesbah, M., Premachandran, U. \& Whitman, W. B. (1989). Precise measurement of the $\mathrm{G}+\mathrm{C}$ content of deoxyribonucleic acid by highperformance liquid chromatography. Int J Syst Bacteriol 39, 159167.

Minnikin, D. E., O'Donnell, A. G., Goodfellow, M., Alderson, G., Athalye, M., Schaal, A. \& Parlett, J. H. (1984). An integrated procedure for the extraction of isoprenoid quinones and polar lipids. J Microbiol Methods 2, 233-241.

Saitou, N. \& Nei, M. (1987). The neighbor-joining method: a new method for reconstructing phylogenetic trees. Mol Biol Evol 4, 406-425.

Sasser, M. (1990). Identification of bacteria by gas chromatography of cellular fatty acids. USFCC Newsl 20, 16.

Schleifer, K. H. (1985). Analysis of the chemical composition and primary structure of murein. Methods Microbiol 18, 123-156.

Schleifer, K. H. \& Kandler, O. (1972). Peptidoglycan types of bacterial cell walls and their taxonomic implications. Bacteriol Rev 36, 407477.

Shirling, E. B. \& Gottlieb, D. (1966). Methods for characterization of Streptomyces species. Int J Syst Bacteriol 16, 313-340.

Stackebrandt, E. \& Schumann, P. (2000). Description of Bogoriellaceae fam. nov., Dermacoccaceae fam. nov., Rarobacteraceae fam. nov. and Sanguibacteraceae fam. nov. and emendation of some families of the suborder Micrococcineae. Int J Syst Evol Microbiol 50, 1279-1285.

Stackebrandt, E., Koch, C., Gvozdiak, O. \& Schumann, P. (1995). Taxonomic dissection of the genus Micrococcus: Kocuria gen. nov., Nesterenkonia gen. nov., Kytococcus gen. nov., Dermacoccus gen. nov., and Micrococcus Cohn 1872 gen. emend. Int J Syst Bacteriol 45, 682692.

Staneck, J. L. \& Roberts, G. D. (1974). Simplified approach to identification of aerobic actinomycetes by thin-layer chromatography. Appl Microbiol 28, 226-231.

Tamura, K., Dudley, J., Nei, M. \& Kumar, S. (2007). MEGA4: molecular evolutionary genetics analysis (MEGA) software version 4.0. Mol Biol Evol 24, 1596-1599.

Zhi, X.-Y., Li, W.-J. \& Stackebrandt, E. (2009). An update of the structure and 16S rRNA gene sequence-based definition of higher ranks of the class Actinobacteria, with the proposal of two new suborders and four new families and emended descriptions of the existing higher taxa. Int J Syst Evol Microbiol 59, 589-608. 